\title{
Targeted CRISPR disruption reveals a role for RNase MRP RNA in human preribosomal RNA processing
}

\author{
Katherine C. Goldfarb ${ }^{1,2}$ and Thomas R. $\operatorname{Cech}^{1,2}$ \\ ${ }^{1}$ Department of Chemistry and Biochemistry, BioFrontiers Institute, University of Colorado at Boulder, Boulder, Colorado 80302 , \\ USA; $^{2}$ Howard Hughes Medical Institute, University of Colorado at Boulder, Boulder, Colorado 80302, USA
}

\begin{abstract}
MRP RNA is an abundant, essential noncoding RNA whose functions have been proposed in yeast but are incompletely understood in humans. Mutations in the genomic locus for MRP RNA cause pleiotropic human diseases, including cartilage hair hypoplasia $(\mathrm{CHH})$. Here we applied CRISPR-Cas9 genome editing to disrupt the endogenous human MRP RNA locus, thereby attaining what has eluded RNAi and RNase H experiments: elimination of MRP RNA in the majority of cells. The resulting accumulation of ribosomal RNA (rRNA) precursor-analyzed by RNA fluorescent in situ hybridization (FISH), Northern blots, and RNA sequencing-implicates MRP RNA in pre-rRNA processing. Amelioration of pre-rRNA imbalance is achieved through rescue of MRP RNA levels by ectopic expression. Furthermore, affinity-purified MRP ribonucleoprotein (RNP) from HeLa cells cleaves the human pre-rRNA in vitro at at least one site used in cells, while RNP isolated from cells with CRISPR-edited MRP loci loses this activity, and ectopic MRP RNA expression restores cleavage activity. Thus, a role for RNase MRP in human pre-rRNA processing is established. As demonstrated here, targeted CRISPR disruption is a valuable tool for functional studies of essential noncoding RNAs that are resistant to RNAi and RNase H-based degradation.
\end{abstract}

[Keywords: CRISPR-Cas9; preribosomal RNA processing; RNase MRP; RNase P; RMRP]

Supplemental material is available for this article.

Received July 7, 2016; revised version accepted December 20, 2016.

MRP RNA is an abundant noncoding RNA (ncRNA) with a reported homolog in all eukaryotes studied to date (Piccinelli et al. 2005; Lopez et al. 2009). Mutations to the single genomic locus for this noncoding transcript cause inviable yeast (Shadel et al. 2000), embryonic lethality in mice (Rosenbluh et al. 2011), and a spectrum of severely debilitating human diseases (Ridanpää et al. 2001), harkening to MRP RNA's essential role in biology.

The MRP RNA has a conserved secondary structure similar to that of the RNA component of RNase P and is assembled into a nucleolar ribonucleoprotein (RNP) complex (Welting et al. 2006; Lopez et al. 2009). In human cells, seven proteins are thought to compose the MRP RNP, and all of these proteins also associate with the $\mathrm{H} 1$ RNA of RNase P (Rosenblad et al. 2006; Welting et al. 2006). Accordingly, since the P RNP is firmly established as the activity responsible for transfer RNA (tRNA) $5^{\prime}$ leader removal via endoribonucleolytic cleavage (Guerrier-Takada et al. 1983), the MRP RNP has also been predicted to have endoribonucleolytic cleavage activity. However, which RNAs does MRP cleave?

Corresponding author: thomas.cech@colorado.edu Article published online ahead of print. Article and publication date are online at http://www.genesdev.org/cgi/doi/10.1101/gad.286963.116.
In budding yeast, affinity-purified MRP RNP can cleave a fragment of the preribosomal RNA (pre-rRNA) internal transcribed spacer 1 (ITS1) at the $\mathrm{A}_{3}$ site (Lygerou et al. 1996), and this site exhibits reduced cleavage at the nonpermissive temperature in temperature-sensitive mutants of the MRP RNA (Chu et al. 1994). While cleavage at the $\mathrm{A}_{3}$ site is not strictly essential in yeast due to redundant backup mechanisms (Henry et al. 1994), it has been reported that MRP RNA is required for pre-rRNA processing, since the entire canonical pathway breaks down with additional mutants of the yeast MRP RNA locus (Lindahl et al. 2009). However, the pre-rRNA processing pathways are distinct in mammalian systems (Mullineux and Lafontaine 2012; Henras et al. 2015), and the ITS1 is particularly not well conserved (361 nucleotides [nt] in yeast and 1078 nt in humans) (Hadjiolova et al. 1993), complicating the characterization of analogous cleavages in humans. In fact, recent work using RNAi on protein components of the P/MRP RNPs found no effect on pre-rRNA processing upon depletion of both RNPs (Sloan et al. 2013).

(C) 2017 Goldfarb and Cech This article is distributed exclusively by Cold Spring Harbor Laboratory Press for the first six months after the full-issue publication date (see http://genesdev.cshlp.org/site/misc/terms.xhtml). After six months, it is available under a Creative Commons License (Attribution-NonCommercial 4.0 International), as described at http://creativecommons.org/licenses/by-nc/4.0/. 
Alternative roles for MRP RNA have been described in yeast and human cells (Chang and Clayton 1987; Gill et al. 2006; Jaag et al. 2011; Mattijssen et al. 2011; Huang et al. 2015), and many of these functions are undoubtedly important for their specific niches (e.g., T lymphocytes). However, these functions are not essential in all cell types that abundantly express MRP RNA. Instead, the vital ubiquity of MRP RNA suggests a common housekeeping function. Here we used disruptive gene editing coupled with in vitro cleavage assays to reveal an essential role for MRP RNA in human cells, a specific step in processing pre-rRNA.

\section{Results}

Nucleolar MRP RNA is poorly targeted by siRNA or RNase $H$

To isolate the role of MRP RNA in human cells, we initially attempted to remove the noncoding transcript via post-transcriptional degradation. Many siRNA and DNA gapmer/antisense oligonucleotide (ASO) reagents failed to affect steady-state MRP RNA abundance, consistent with previous reports (Mattijssen et al. 2011). In our hands, only a single siRNA sequence targeting nucleotides 135-154 of MRP RNA achieved modest depletion of MRP RNA by quantitative RT-PCR (qRT-PCR) and RNA fluorescent in situ hybridization (FISH) (Supplemental Fig. S1). Strikingly, disruption of the nucleolar structure (Supplemental Fig. S1C) as well as broad flattened cellular morphology and cell cycle perturbations (Supplemental Fig. S1D,E) accompanied this modest depletion of the target MRP RNA, suggesting off-target effects. Indeed, cells treated with this siRNA showed depletion of nontarget RNAs (Supplemental Fig. S1A), including the messenger RNAs (mRNAs) for two of the MRP/P RNP proteins: hPOP1 and Rpp25. Upon inspection of the hPOP1 mRNA, numerous seed matches for this siRNA were present in the hPOP1-coding region (Supplemental Fig. S1F). While it is intriguing that an siRNA targeting the ncRNA subunit of RNase MRP would also target the messages for its protein subunits and that microRNAs (miRNAs) derived from the MRP RNA locus closely overlap the siRNA sequence examined here (Rogler et al. 2014), this reagent's effect was too pleiotropic to examine MRP RNA-specific function and was not pursued further.

\section{CRISPR-Cas9 efficiently disrupts the MRP $R N A$ locus}

Since MRP RNA, like many stably folded protein-coated nuclear or nucleolar ncRNAs, is not well suited for depletion mechanisms targeting the RNA, we opted to mutate the genomic locus $(R M R P)$ as a means of specifically and effectively disrupting MRP RNA function. Transfection of Cas9 with four independent CRISPR guides efficiently cleaved the RMRP genes in HeLa cells (Fig. 1A,B). Pairs of nonoverlapping guides resulted in removal of the predict-

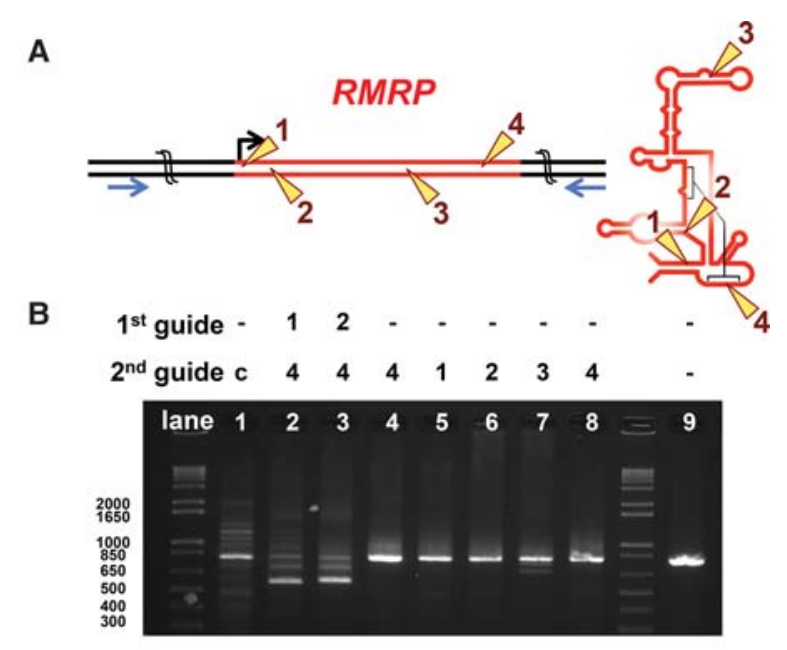

\section{C}
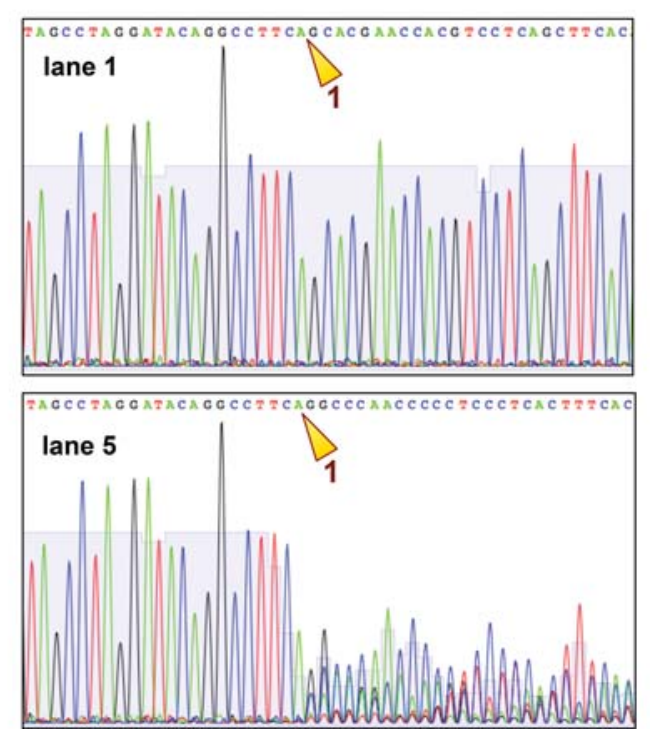

Figure 1. The MRP RNA locus is efficiently edited by CRISPR-Cas9 in human cells. (A) Schematic of the RMRP locus and the MRP RNA secondary structure. Numbers 1-4 designate the CRISPR-mediated cut sites described in this work. (Yellow arrowheads) Positions where CRISPR-mediated cleavages map to $R M R P$ and to the RNA secondary structure; (blue arrows) PCR primers used in $B$. (B) PCR amplicons of genomic DNA from control and edited populations of HeLa cells $33 \mathrm{~h}$ after transfection of CRISPR-Cas9 machinery. CRISPR guides targeting the cut sites described in $A$ are indicated for each reaction. (C) Representative sequence traces of gel-purified PCR amplicons from two lanes of $B$. (Top panel ["lane 1"]) The unique $R M R P$ sequence is observed across the population of HeLa cells treated with nontargeting CRISPR guide. (Bottom panel ["lane $5^{\prime \prime}$ ) Different indels at the cut site present in the RMRP guide-treated population cause superposition of multiple sequences. For the genotypes of individual clonal lines, see Supplemental Figure S2.

ed genomic fragment (Fig. 1B, lanes 2,3), and single guides left small nucleotide insertion/deletion (indel) scars at the precise cleavage site in both polyclonal edited populations (Fig. 1C) and individual monoclonal cell lines (Supplemental Fig. S2). 


\section{Mutation of RMRP causes severe proliferation defects}

As cells treated with single CRISPR guides had mutations at their MRP RNA loci, we next sought to capitalize on these indels and isolate stable clonal cell lines with distinct mutated genotypes. In agreement with reports that MRP RNA is essential (Rosenbluh et al. 2011), many clones exhibited striking proliferative arrest after exposure to $R M R P$ targeting guides (Fig. 2A,B). RNA FISH revealed that MRP RNA was undetectable in arrested clones compared with control clones (Fig. 2C). Any clones found proliferating robustly after treatment with $R M R P$ targeting CRISPR guides also had abundant MRP RNA by FISH (Fig. 2B,C), suggesting either that these cells escaped transfection or that CRISPR cleavage in these cells resulted in faithful (or at least innocuous) repair. From these data, we estimate that $40 \%-80 \%$ of HeLa cells

A
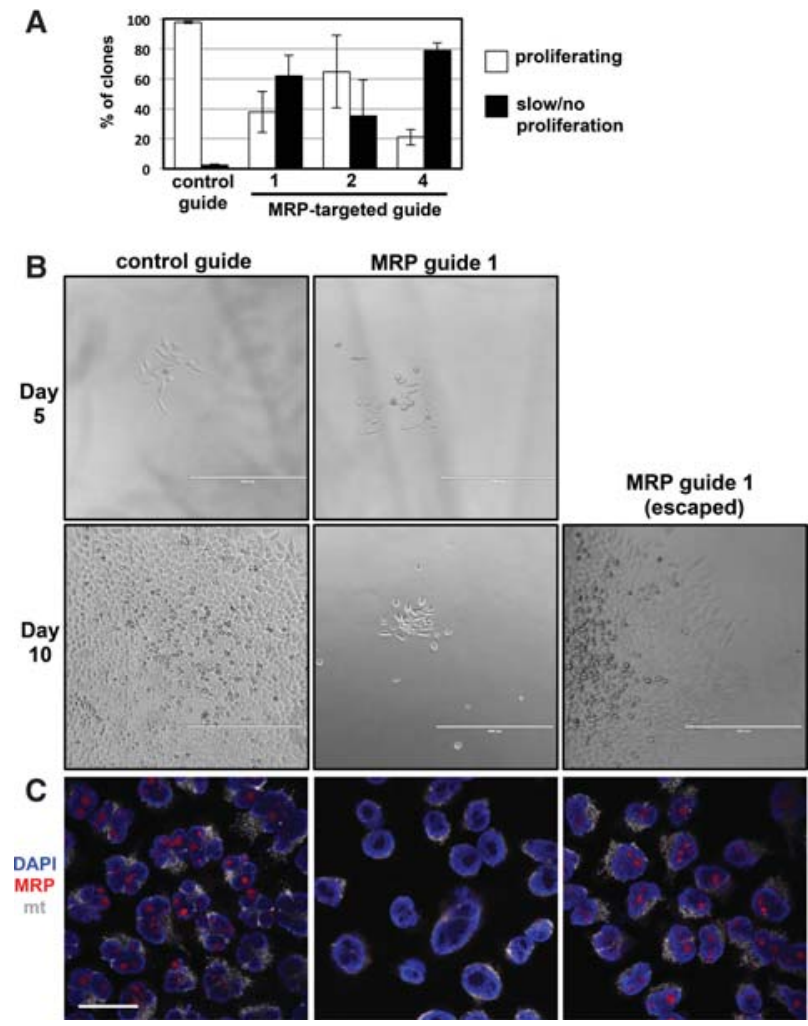

Figure 2. CRISPR editing of $R M R P$ abolishes MRP RNA expression and inhibits cell proliferation. $(A)$ Growth characteristics of cells cloned after CRISPR-Cas9 treatment. Colonies were identified at day 5 and then photographed again at days 10-14. "Proliferating" colonies had cell proliferation greater than the field of view $(1.1 \mathrm{~mm} \times 0.8 \mathrm{~mm})$ by day 14 , and "slow/no proliferation" colonies had as many as 50 cells by day 14 or as few as the same number cells as on day 5. Error bars indicate the range of two biological replicates, analyzing at least 50 clones for each guide. $(B)$ Example "proliferating" colonies (left and right panels) and "slow/no proliferation" colonies (middle panels). Bar, $400 \mu \mathrm{m}$. "Escaped" refers to a colony that eluded CRISPR disruption. $(C)$ RNA FISH of the bottom panels in $B$ with MRP RNA in red, DAPI-stained nuclei in blue, and mitochondria $(\mathrm{mt})$ in gray. Bar, $30 \mu \mathrm{m}$. For comparison with siRNA depletion, see Supplemental Figure S1. transfected with Cas9 and RMRP targeting CRISPR guides were deleteriously edited under our conditions (Fig. 2A). We use the term "targeted CRISPR disruption" to describe the heterogeneous $R M R P$ loci deleteriously edited by $R M R P$ targeted CRISPR guides. The inverse relationship between population doubling and MRP RNA disappearance from $R M R P$ targeted CRISPR disruption supports the conclusion that MRP RNA is essential for proliferation of this HeLa cell line.

\section{Cells lacking MRP RNA accumulate rRNA precursors}

Because pre-rRNA is reported to be an essential substrate of RNase MRP in yeast (Chu et al. 1994), we first investigated rRNA levels in our MRP RNA-deficient clones using two-color FISH. In contrast to all proliferating clones, arrested clones void of MRP RNA displayed enlarged nucleoli with a bold 5.8S rRNA signal (Fig. 3A), consistent with a defect in nucleolar pre-rRNA processing. Hybridization to 5.8S rRNA could result from accumulation of either the mature rRNA or various precursors. The nucleolar rRNA signal was confirmed to reside within pre-rRNA using a probe complementary to the ITS1 region, which gave a purely nucleolar signal. Control cells with high MRP RNA levels had a very low ITS1 signal, but nonproliferating MRP RNA-negative cells gave a strong ITS1 signal (Fig. 3B). This anti-correlation was particularly clear in a mixed population, where cells devoid of MRP RNA accumulated ITS1 signal relative to their MRP RNA-positive neighbors (e.g., Fig. 3B, bottom row, circled cells).

\section{Pre-rRNA buildup is mostly $5^{\prime}$ of $5.8 \mathrm{~S}$}

To home in on the mechanism by which removal of MRP RNA leads to accumulation of pre-rRNA, we aimed to assess which portions of the pre-rRNA were being stabilized when MRP RNA was missing. Insufficient proliferation of isolated clones completely devoid of MRP RNA (Fig. 2) prohibited bulk analysis of total RNA from efficiently edited monoclonal cell lines. However, treatment with Cas9 and a CRISPR guide targeting $R M R P$ resulted in a composite population containing many MRP RNA-negative cells that had been disrupted at the $R M R P$ locus as well as some cells with repaired $R M R P$ that still expressed MRP RNA (Figs. 2, 3). Since CRISPR-mediated disruption of $R M R P$ demonstrated loss of MRP RNA and accumulation of pre-rRNA on the single-cell level (Fig. 3), we reasoned that pre-rRNA accumulation in these MRP RNA-negative cells would also be detectable among the bulk total RNA of the composite population. This composite population is referred to here as an "MRP RNA-depleted population," reflecting that once cells are lysed for bulk RNA analysis, composite MRP RNA levels are reduced as a result of averaging RNA levels across many cells with no MRP RNA and a few cells retaining MRP RNA.

Indeed, Northern analysis demonstrated that MRP RNA levels were reduced in composite populations of HeLa cells by $4 \mathrm{~d}$ after treatment with $R M R P$ targeting CRISPR guides (Fig. 4A). Although mature rRNA levels 


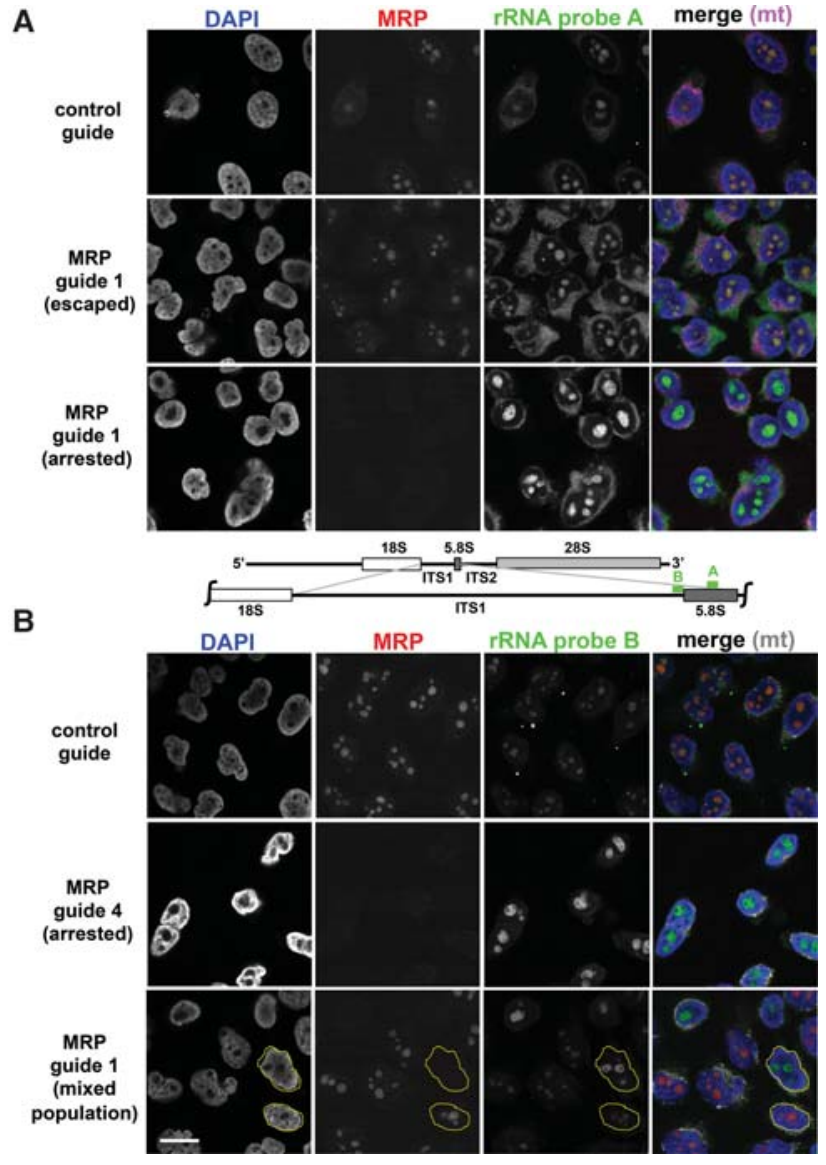

Figure 3. Pre-rRNA accumulates in cells void of MRP RNA. (A) Two-color RNA FISH of representative control and $R M R P$-edited colonies with MRP RNA in red, DAPI-stained nuclei in blue, 5.8S rRNA in green, and mitochondria $(\mathrm{mt})$ in pink (to distinguish mitochondrial signal from the cytoplasmic rRNA signal). (Escaped) A colony that eluded CRISPR disruption; (arrested) a colony that ceased to proliferate. (B) Two-color RNA FISH as in $A$ except with ITS1 probe B in green and mitochondria $(\mathrm{mt})$ in gray. The schematic in the middle indicates where the green probes for $A$ and $B$ hybridize to the pre-rRNA. Mature rRNAs are depicted in white (18S), dark gray (5.8S), and light gray (28S). (Mixed population) The polyclonal MRP RNA-depleted population discussed in the text. (Yellow outlines) Two example cells that illustrate anti-correlated MRP RNA and ITS1 signals. Bar, $20 \mu \mathrm{m}$. Larger fields of view are shown in Supplemental Figure S3.

were largely unchanged or slightly depleted (Fig. 4B), certain rRNA processing intermediates accumulated in MRP RNA-depleted populations (Fig. 4C,D). These intermediates (Fig. 4D) included the normally low abundance 41S as well as alternative intermediates 21SL3' (Sloan et al. 2013) and X (see Fig. 4 legend) that are below detection in control cells. All of these stabilized species represent rRNA precursors whose ITS1 is still intact (Fig. 4C, schematic at left), suggesting that elimination of MRP RNA in these cells leads to the accumulation of uncleaved ITS1. In concert with this hypothesis, precursors with productively cleaved ITS1 (i.e., 30S, 26S, 21S, and 32S) are less abundant in cells missing MRP RNA (Fig. 4).
Furthermore, ectopic expression of MRP RNA, which rescues MRP RNA levels in MRP RNA-depleted populations (Fig. 5A-C), ameliorates this imbalance of rRNA precursors (Fig. 5D,E). The rescue of pre-rRNA processing is most readily seen in the disappearance of the $21 \mathrm{SL} 3$ ' intermediate, a more subtle decrease in the $41 \mathrm{~S}$ intermediate, and the increase in mature $28 \mathrm{~S}$ and $18 \mathrm{~S}$ rRNAs (Fig. 5D, E). For unknown reasons and despite comparable expression of ectopic MRP RNA (Fig. 5B), pre-rRNA processing defects observed with CRISPR guides 1 and 2 are rescued with ectopic wild-type MRP RNA (Fig. 5E, lanes 4,6), while defective pre-rRNA processing seen with guide 4 remains uncorrected (Fig. 5D [lanes 7 vs. 8], E [lane 8]).

For a more comprehensive picture of pre-rRNA abundance, we performed RNA sequencing (RNA-seq) of control and MRP RNA-depleted populations. Because coverage of the mature and precursor rRNAs was required, total RNA was used to prepare RNA-seq libraries. (Accordingly, while libraries prepared from biological duplicate experiments provided ample coverage over the vast majority of the pre-rRNA gene [ 42 million to 65 million reads per sample mapped to the pre-rRNA locus; 100,000-220,000 reads per sample mapped to nonmature sequences], the depth of mRNA coverage from this data set was insufficient for analysis.) To visualize which regions of the rRNA gene were enriched in MRP RNA-depleted samples, an enrichment ratio was calculated by taking the coverage at each base for the MRP RNA-depleted sample divided by the average coverage in control samples. Biological replicates treated with the same CRISPR guide displayed highly similar profiles of pre-rRNA base abundance enriched over control (see peaks in Fig. 4F). Consensus regions of the rRNA gene enriched in all MRP RNA-depleted samples over control samples were limited to precursor regions rather than mature regions but were not limited to ITS1, spanning many regions of the precursor $5^{\prime}$ of the 5.8S. In particular, MRP RNA-depleted populations showed accumulation of sequence reads in regions previously identified as endonucleolytic cleavage sites in the pre-rRNA (Fig. 4F, bottom diagram, vertical lines; Henras et al. 2015). This suggests that the role of MRP RNA in prerRNA processing is either multifaceted (i.e., MRP RNA makes multiple cleavages in pre-rRNA) or early (i.e., MRP RNA may contribute to an initial requisite cleavage for the continuation of pre-rRNA processing).

\section{Immunopurified human MRP RNP specifically cleaves fragments of human pre-rRNA}

To home in on putative cleavage sites within these MRP RNA-dependent stabilized regions of pre-rRNA and independently verify cleavage activity by the MRP RNP, we established an in vitro system using affinity-purified $\mathrm{MRP} / \mathrm{P}$ RNP. (We use the term "MRP/P" to indicate the mixture of these two RNPs, which copurify because of their shared protein components.) Others (Welting et al. 2006; Mattijssen et al. 2011) have shown that N-terminal tags on MRP/P protein components enable immunopurification of pre-tRNA cleavage activity from human cells. Building on these observations and in response to 
A
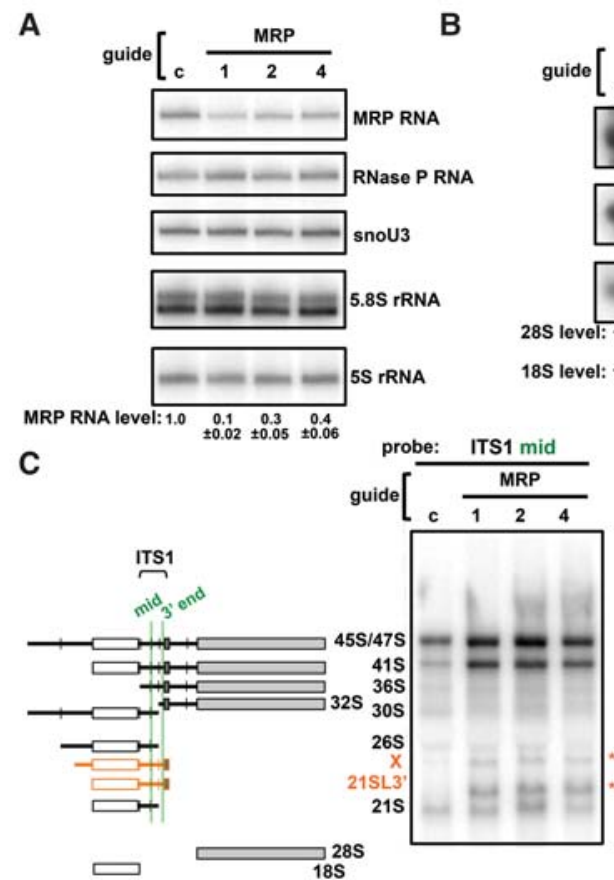

E
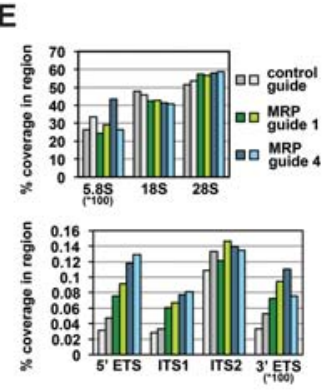

B

$F$

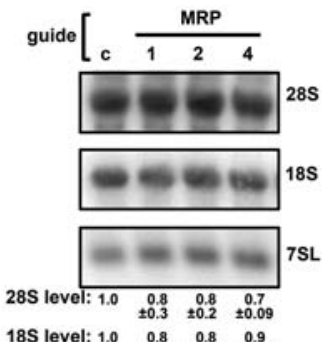

$18 \mathrm{~S}$ level: $1.00 \begin{array}{cccc}0.8 & 0.8 & 0.9 \\ 00.2 & 0.04 & 0.07\end{array}$
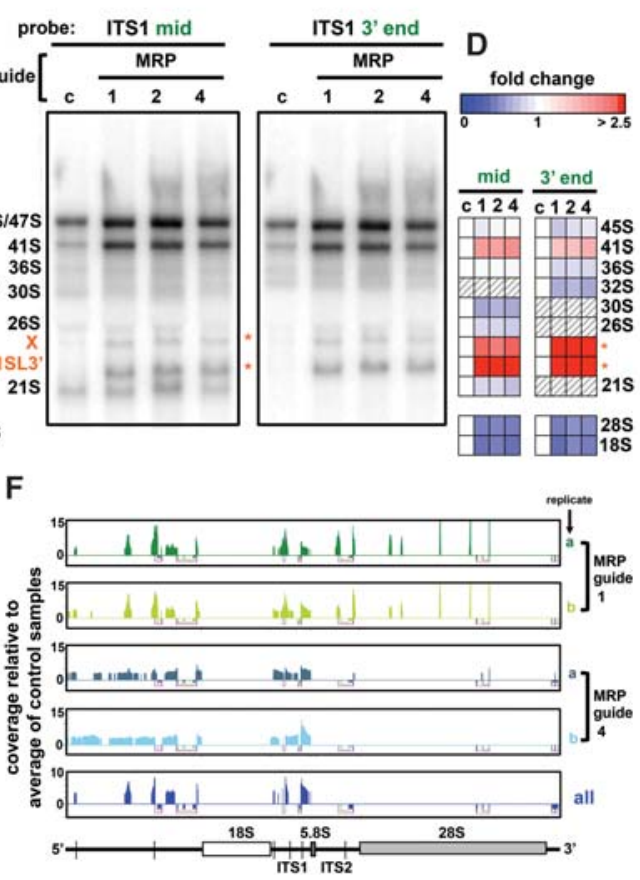

Figure 4. CRISPR removal of MRP RNA in HeLa populations impacts steady-state expression of rRNA precursors. $(A)$ Northern analysis from composite HeLa populations treated $4 \mathrm{~d}$ before harvest with control or RMRP targeting CRISPR guides 1, 2, and 4. Mean MRP RNA level relative to the nontargeting control guide is given with the standard error for six biological replicates. (c) Nontargeting control guide. (B) Northern analysis of mature rRNAs from HeLa populations in A. Mean 28S and 18S rRNA levels relative to the nontargeting control guide are given with the standard error for three biological replicates. (7SL) Loading control. (C) Northern analysis of rRNA precursors from HeLa populations in A. (Left) The schematic indicates where Northern probes (green) align within the ITS1 of pre-rRNA and the approximate composition of each RNA species. (Orange diagrams and asterisks) Noncanonical precursors that are stabilized in the absence of MRP RNA; $(\mathrm{X})$ previously unidentified precursor containing intact ITS1, with the predicted composition depicted. $(D)$ Quantification of rRNA precursors in $C$. The heat map depicts the fold change of each precursor relative to its level with the nontargeting control guide (shown in lane $c)$. Average fold change for six biological replicate blots. (White) 1.0; a level equal to the control; (gray hatched boxes) RNAs that are not observable with the ITS1 probe indicated. Heat maps and fold change values for individual replicate blots are in Supplemental Figure S4. (E) RNA sequencing (RNA-seq) read coverage across mature and precursor rRNA for MRP RNA-depleted and control cells. Read coverage was determined by the number of reads that aligned to a given region, scaled to the total reads that aligned to the entire full-length pre-rRNA for each sample indicated. The $5.8 \mathrm{~S}$ and $3^{\prime}$ ETS were further scaled to enable graphing on the same axes since these had 100fold lower coverage than the other mature or precursor regions, respectively. $(F)$ Individual nucleotide coverage of RNA-seq reads for MRP RNA-depleted and control cells. The read coverage at every nucleotide along the rRNA precursor ( $X$-axis) was first scaled to total number of reads that mapped to the entire rRNA precursor for each sample. This scaled coverage for each MRP RNA-depleted library was further normalized to the average of control samples at that nucleotide position to achieve the relative coverage at each nucleotide position. Only relative coverage at least threefold greater than average control samples is shown. (Bottom panel ["all"]) Nucleotide positions that are at least threefold enriched in all MRP RNA-depleted replicates over control replicates. Vertical lines on the schematic at the bottom indicate the approximate positions of endonucleolytic cleavages. Lines below the $X$-axis on each graph indicate nucleotide positions with zero coverage in at least one control sample (purple), zero coverage in both control samples (pink), and zero coverage in all samples (bright green).

ineffective isolation of RNase MRP via tagging the MRP RNA (data not shown), we constructed 3xFlag-Rpp25 and 3xFlag-Rpp38 for transfection in HeLa cells (see the Supplemental Material). We then immunopurified 3xFlag-RNPs, eluting with Flag peptide (Fig. 6).

Flag elutions from cell extracts expressing 3xFlagRpp25 contained other MRP/P RNP proteins as well as both MRP and P RNAs, while other abundant nuclear proteins (RNA polymerase II [RNAPII]) and RNAs (snoRNA U3) were removed in high-salt washes (Fig. 6A, lanes 13). Rpp25 forms an obligate heterodimer with Rpp20, and, as observed previously (Welting et al. 2007), endogenous Rpp20 levels were elevated by expression of exogenous 3xFlag-Rpp25. This excess endogenous Rpp20 is almost entirely associated with the elution fraction after purification (Fig. 6A, lane 3), indicating that our tagged construct remains functional at least for heterodimer formation (Fig. 6A, cf. lanes 1 and 4 and 7). 3xFlag-Rpp38 expressed at lower levels in our hands, and, while elutions from lysates of cells expressing 3xFlag-Rpp38 contained lower levels of $\mathrm{P}$ and MRP RNAs as well as traces of hPOP1, endogenous Rpp20 and Rpp30 were below our detection limit in these preparations (Fig. 6A, lanes 4-6).

Because our tagged constructs encode proteins that are present in both RNase MRP and RNase P RNPs, we could capitalize on established RNase P activity assays (Guthrie 1975; Guerrier-Takada et al. 1983) as a control for the preservation of enzymatic activities in our preparations. All of our 3xFlag-Rpp25 and 3xFlag-Rpp38 elutions, but not those from cells without $3 x$ Flag constructs, were highly 


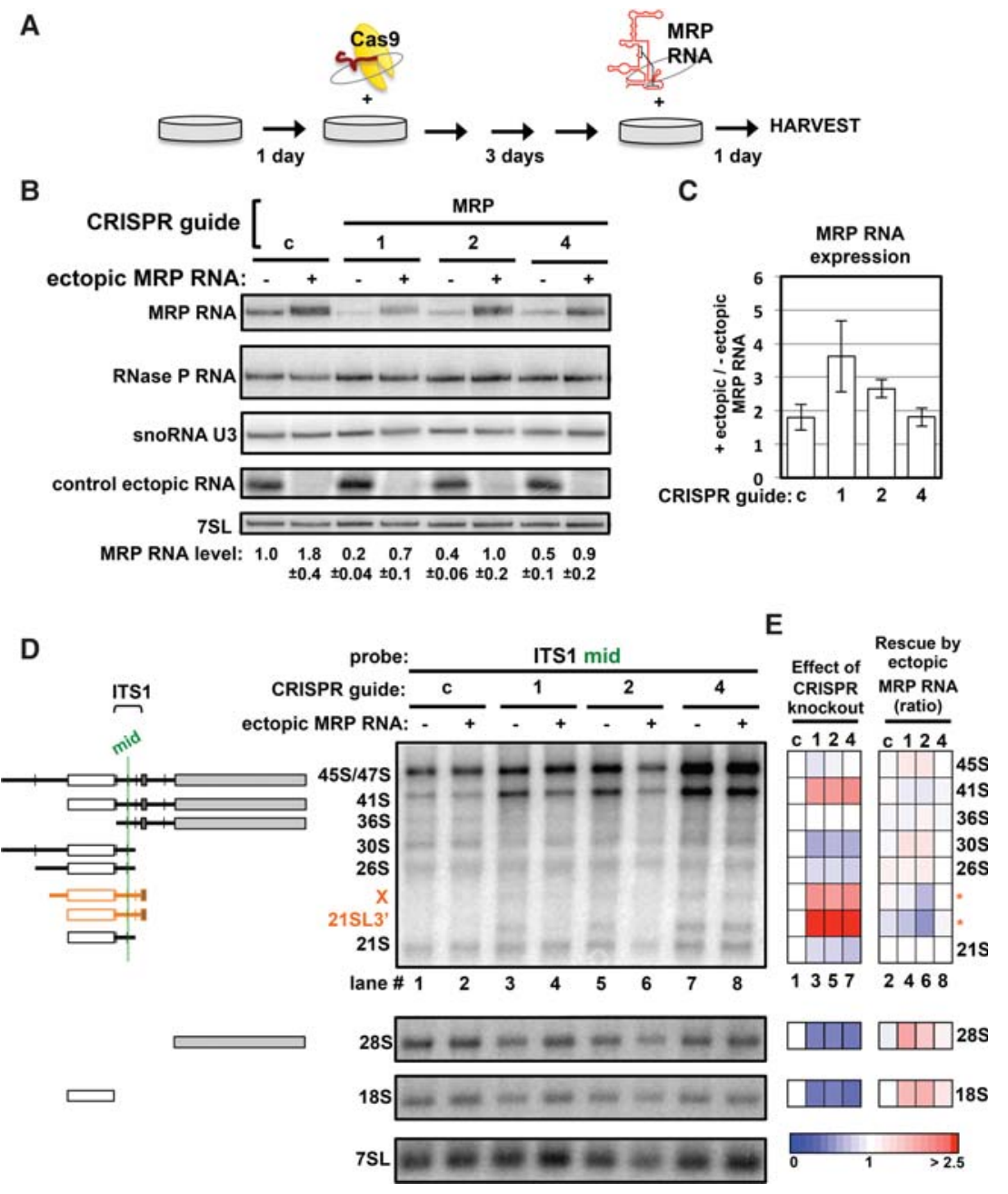

Figure 5. Exogenous expression of MRP RNA restores pre-rRNA processing in cells disrupted at $R M R P$. (A) Schematic for ectopic MRP RNA expression after CRISPR-Cas9 treatment. Plasmids encoding Cas9 and CRISPR guides were transfected $3 \mathrm{~d}$ before a plasmid for ectopic MRP RNA expression driven by the human $R M R P$ promoter. Details are described in the Materials and Methods. (B) Northern analysis from composite HeLa populations treated according to the schematic in $A$ with ectopic MRP RNA (+) or a plasmid that expresses a control RNA sequence driven by the same $R M R P$ promoter $(-$; control ectopic RNA). Mean MRP RNA level relative to the nontargeting control guide is given with the standard error for four biological replicates. (c) Nontargeting control guide. (C) MRP RNA levels increase after ectopic expression of MRP RNA. Error bars indicate the standard error of the mean for four biological replicates. $(D)$ Northern analysis of mature and precursor rRNAs from HeLa populations in $B$. (Left) The schematic indicates where the " $\mathrm{mid}^{\prime}$ Northern probe (green) aligns within the ITS 1 of pre-rRNA and the approximate composition of the pre-rRNAs labeled. (Orange) Noncanonical precursors that are stabilized in the absence of MRP RNA and partially depleted with ectopic MRP RNA expression. (E) Quantification of rRNA precursors in $D$. (Orange asterisks) Noncanonical precursors defined in $D$. (Left heat map) The effect of MRP RNA disruption in the absence of ectopic MRP RNA expression (as in Fig. 4D). (Right heat map) The effect of ectopic MRP RNA expression shown as the ratio of each RNA species with or without ectopic MRP RNA. Both heat maps present the mean fold changes for five biological replicate blots. Heat maps and fold change values for individual replicate blots are in Supplemental Figure S4C.

competent for cleavage of body-labeled pre-tRNA (Fig. 6C; Supplemental Fig. S5).

To distinguish RNase P from RNase MRP functionality with this assay, we also affinity-purified $3 \times$ Flag-containing RNPs from cells cotransfected with 3xFlag-Rpp25 and Cas9-CRISPR guides that targeted either RMRP or a nonhuman control locus. As observed for Flag elutions from cells without the CRISPR machinery (Fig. 6A), elutions from cells with the nontargeting control guide contained both P and MRP RNPs (Fig. 6B, lane 6; Supplemental Fig. S5A [lane 5], B [lane 4]). However, Flag elutions from cells with RMRP targeting CRISPR guides displayed severely diminished MRP RNA levels (as expected with composite populations) while retaining RNase P RNA and various protein components (Fig. 6B; Supplemental Fig. S5A,B). As expected, Flag elutions from cells treated with either control or RMRP targeting CRISPR guides also retained robust pre-tRNA cleavage activity (Fig. 6C).

We then challenged our affinity-purified MRP/P RNPs with body-labeled RNA substrates corresponding to regions ( 200 nt in length) along the rRNA precursor (Sup- plemental Fig. S6). Putative substrates were designed to span predicted pre-rRNA cleavage sites (Henras et al. 2015) as well as sequences stabilized in an MRP RNA-dependent manner from our RNA-seq data (Fig. 4F; Supplemental Fig. S6B). Intriguingly, precise endonucleolytic cleavage by 3xFlag-Rpp25 elutions was observed for several but not all pre-rRNA substrates tested (Supplemental Fig. S6C). While characterization of each of these putative cleavage sites is beyond the scope of this work, the stabilization of these sequences in cells lacking MRP RNA and their precise cleavage by the MRP RNP in vitro suggest that the MRP RNP may directly cleave multiple sites within the human rRNA precursor.

\section{Pre-rRNA site 2 is cleaved by human MRP RNP in vitro}

We focused on the substrate spanning site 2 in the ITS1 region for several reasons: (1) This substrate overlapped the in situ hybridization probe that displayed an anti-correlated signal with MRP RNA (Fig. 3). (2) This substrate most closely correlated with the specifically stabilized 
A

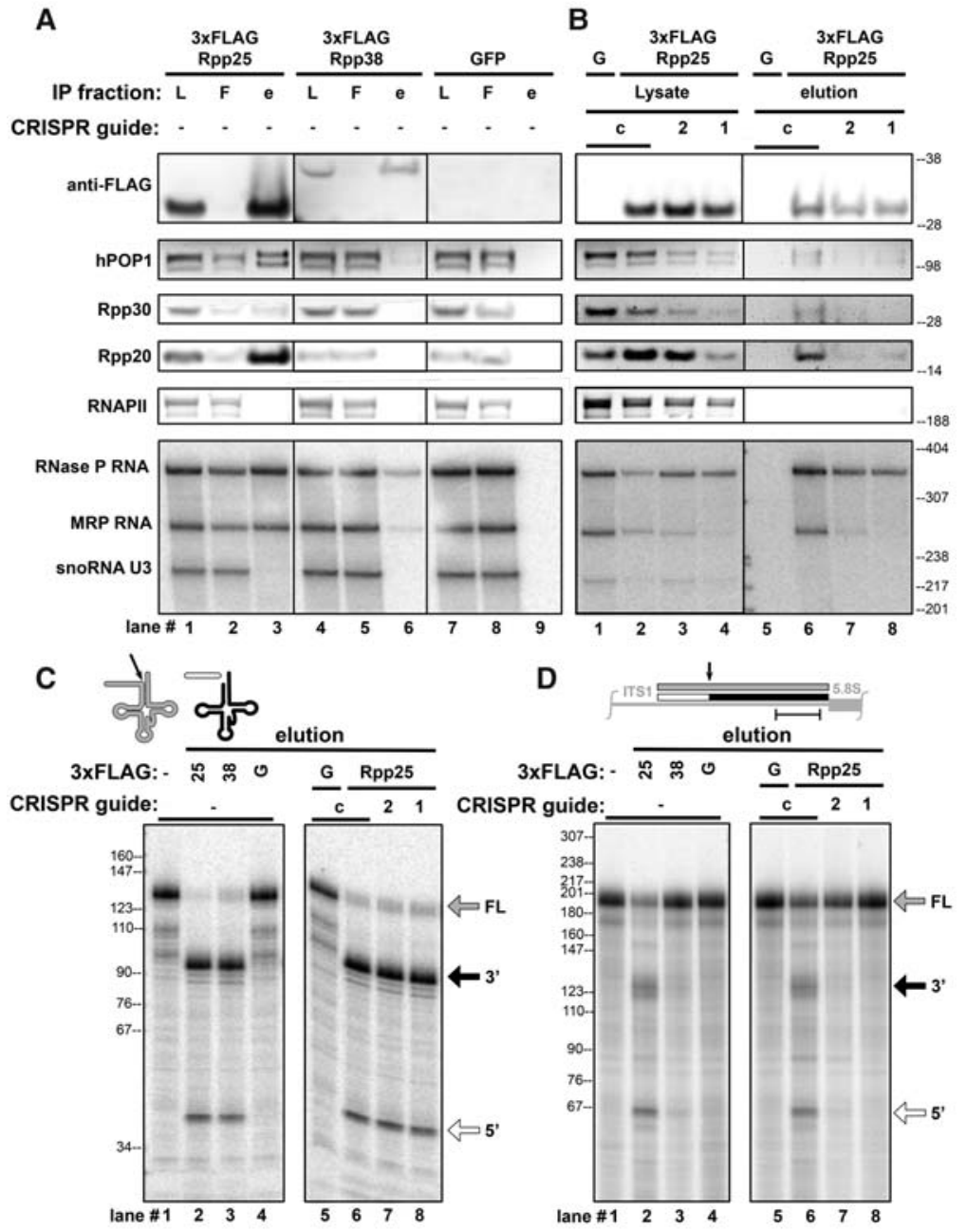

Figure 6. Affinity-purified MRP RNP cleaves a prerRNA substrate at site 2 in vitro. (A) Immunopurification and elution of MRP/P RNPs from cells transfected with 3xFlag-tagged protein constructs. (L) Wholecell lysate; (F) flowthrough of material not bound to beads; (e) Flag peptide elution from beads; (hPOP1, Rpp30, and Rpp20) representative proteins of the MRP/P RNP; (RNA polymerase II [RNAPII] and snoRNA U3) specificity controls for the immunoprecipitation; (GFP transfection) a control for perturbations caused by transfection and for contaminating activities from the beads or elution conditions. $(B)$ Composition of MRP/P RNPs from cells cotransfected with CRISPR guides and 3xFlag-Rpp25. (G) GFP transfection as in $A_{\text {; }}$ (c) control guide. Size markers are indicated at the right in kilodaltons for protein blots (top five panels) and DNA base pairs for RNA blots (bottom panel). $(C)$ In vitro cleavage of pretRNA $^{\text {TYR }}$ by the RNPs eluted in $A$ and $B$. Full-length (FL) pre-tRNA is indicated in gray, the $5^{\prime}$ cleavage product is indicated in white, and the $3^{\prime}$ (mature) product is indicated in black. The slender arrow highlights the RNase P cleavage site. $(D)$ In vitro cleavage of human pre-rRNA ITS1 substrate by the RNPs eluted in $A$ and $B$. The schematic highlights the placement of the ITS1 substrate (gray bar) within the rRNA precursor. The slender vertical arrow indicates the site 2 cleavage site observed in cells (Supplemental Figure S7), and white and black designate the $5^{\prime}$ and $3^{\prime}$ cleavage products, respectively. Bar, $50 \mathrm{nt}$. Additional affinity purifications with activity assays as well as activity assays with extended pre-rRNA substrates are in Supplemental Figures S5, S6, and S8. precursors in Northern analysis (Figs. 4, 5). (3) This substrate encompassed the human cut site 2 , an essential cleavage for the maturation of human pre-rRNA and potentially analogous to the yeast $\mathrm{A}_{3}$ site cleaved by the yeast MRP RNP (Chu et al. 1994; Lygerou et al. 1996). In vitro cleavage of the ITS1 site 2 substrate produced a cut in the vicinity of the sequence "...UCUCCGGA GUC^CGGUCCCGUU..." 135-140 nt upstream of the mature $5^{\prime}$ end of $5.8 \mathrm{~S}$ rRNA (Fig. 6D). The $5^{\prime}$ end produced by this cleavage closely resembled those observed by primer extension to be diminished in cells lacking MRP RNA (Supplemental Fig. S7A).

In contrast to pre-tRNA cleavage, which was unaffected by MRP RNA disruption, the ITS1 site 2 substrate cleavage occurred only with elutions containing MRP RNA (Fig. 6D; Supplemental Fig. S5C,D). Substrate RNAs with longer sequences that extended further $3^{\prime}$ or $5^{\prime}$ of the original substrate in Figure 6D were cleaved with similar efficiency and substantiated the assignment of the cleavage products (Supplemental Fig. S8). Finally, ectopic expression of MRP RNA $24 \mathrm{~h}$ before cell harvest for RNP immunoprecipitation rescued MRP RNA levels in the eluted RNP (Fig. 7) and restored cleavage of the ITS1 site 2 substrate without substantially affecting cleavage of
pre-tRNA by copurified RNase P (Fig. 7C,D). Together, these data support the conclusion that MRP RNA is required for site 2 cleavage in human cells.

\section{Discussion}

The essential function of MRP RNA in human cells has remained controversial for $>30$ years (Mattijssen et al. 2010). Here we provide genetic, cytological, and biochemical evidence that RNase MRP catalyzes at least one key step in the pre-rRNA processing cascade, the endonucleolytic cleavage that separates the $18 \mathrm{~S}$ rRNA from the $5.8 \mathrm{~S}-$ $28 \mathrm{~S}$ portion of the rRNA precursor. We also present preliminary sequencing and biochemical evidence for putative MRP RNP-catalyzed cleavage at additional sites within human pre-rRNA (Fig. 4F; Supplemental Fig. S6). Together, we posit that MRP RNA contributes essential pre-rRNA processing for human cells.

\section{CRISPR disruption enables population study of essential $n c R N A s$}

Many nuclear and nucleolar ncRNAs are essential components of biological processes but have eluded 
A
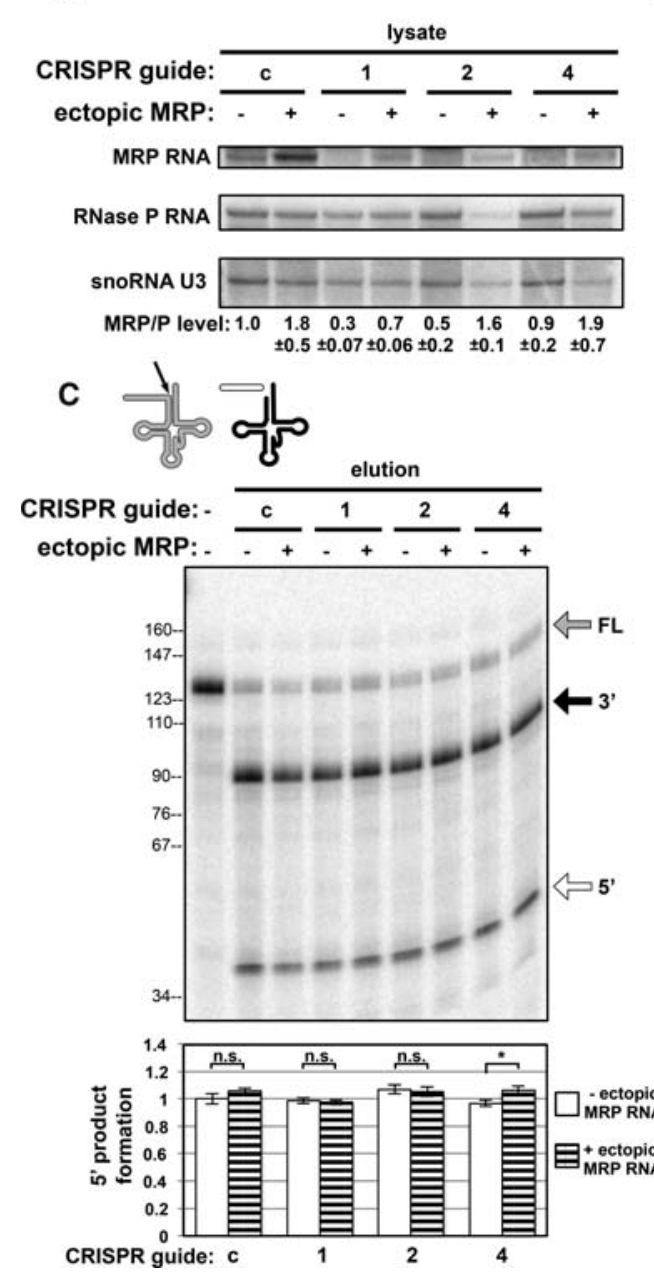

B

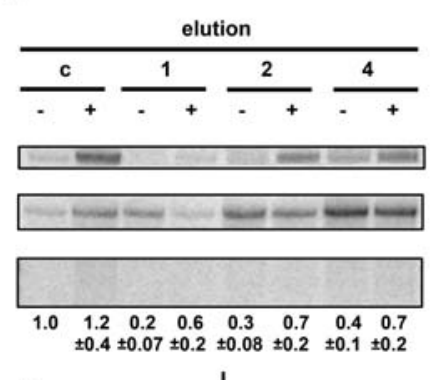

D
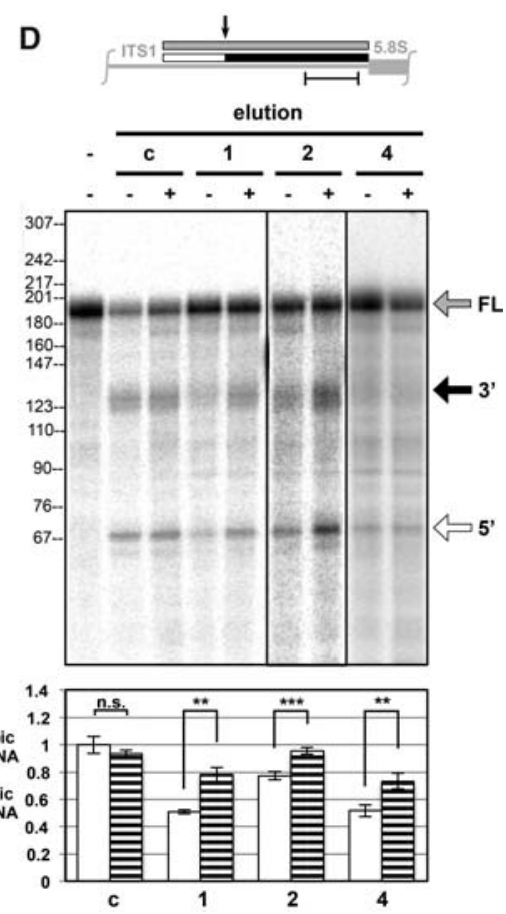

Figure 7. Expression of ectopic MRP RNA restores cleavage of pre-rRNA in vitro. $(A)$ Ectopic MRP RNA expression assessed by Northern analysis. Lysates were prepared as per Figure $5 \mathrm{~A}$, with the exception that the plasmid containing 3xFlag-Rpp25 was cotransfected with the CRISPR machinery (see the Materials and Methods). The mean ratio of MRP RNA to RNase P RNA is indicated for comparison with the elution in $B$, with the standard error for three biological replicate experiments. $(B)$ Northern analysis of $3 x$ Flag peptide elutions from antiFlag immunoprecipitations performed with the lysates in $A$. The ratios of MRP RNA to RNase P RNA indicate that ectopic MRP RNA is immunoprecipitated along with endogenous MRP RNA. Mean ratios are given with the standard error for three biological replicate experiments. $(C)$ In vitro cleavage of pre-tRNA ${ }^{\text {TYR }}$ by the RNPs eluted in $A$ and $B$. Full-length (FL) pretRNA is indicated in gray, the $5^{\prime}$ cleavage product is indicated in white, and the $3^{\prime}$ (mature) product is indicated in black. The slender arrow highlights the RNase P cleavage site. The bar graph quantifies $5^{\prime}$ product formation as a proxy for cleavage activity. Error bars indicate the standard error of four replicate assays. (n.s.) Nonsignificant; $(*) P=$ 0.03 . (D) In vitro cleavage of human prerRNA ITS1 substrate by the RNPs eluted in $A$ and $B$. Black lines indicate where intervening lanes have been removed. The schematic highlights the placement of the ITS1 substrate (gray bar) within the rRNA precursor. The slender arrow indicates the site 2 cleavage site, and white and black designate the $5^{\prime}$ and $3^{\prime}$ cleavage products, respectively. Bar for schematic, $50 \mathrm{nt}$. The bar graph below quantifies $5^{\prime}$ product formation as a proxy for cleavage activity. Error bars indicate the standard error of the mean for four (control guide) and six $\left(R M R P\right.$ targeting guides) replicate assays. $\left(^{* *}\right) P<0.01$; ${ }^{(* * *)} P<0.001$; (n.s.) nonsignificant. A shorter exposure of each gel with all bands unsaturated was used for quantification.

knockdown methods such as siRNAs due to their subcellular localization, stable three-dimensional structures, complex biogenesis, and/or ubiquitous status in RNPs (Barrangou et al. 2015). Furthermore, the vital nature of many of these transcripts renders traditional stable gene mutation/deletion impossible. While conditional deletion methods such as the TET system have made great strides in the mRNA field, most of these are tuned for RNAPII promoters or are reliable only for induction (not repression) of RNAPIII promoters (Amar et al. 2006). In light of this deficiency, we developed a CRISPR-mediated disruption method to target the comparatively accessible genomic locus RMRP, encoding the essential and protein-coated MRP RNA. Using this method, we were able to efficiently perturb $R M R P$ at three distinct target locations, quench MRP RNA expression in the majority of cells, and observe the acute accumulation of pre-rRNA substrate accompanied by arrested cell division (Figs. 1-4). Subsequent ectopic expression of MRP RNA ameliorated this accumulation (Fig. 5). RMRP loci mutated by all three $R M R P$ targeting CRISPR guides were also sufficient to render immunopurified RNP from these cells incapable of cleaving the ITS1 RNA in vitro (Fig. 6), while cleavage was recovered upon ectopic expression of MRP RNA (Fig. 7), illustrating the robust application of this technique for understanding the function of an essential RNA.

Why have previous studies not seen pre-rRNA processing defects upon MRP depletion?

Sloan et al. (2013) reported clear evidence against any perturbation in pre-rRNA processing in the context of RNAi against protein subunits of the MRP/P RNP; despite at least $80 \%$ depletion of $\mathrm{P}$ and MRP RNAs, pre-rRNA processing was unaffected. The key difference with our CRISPR disruption system may be attributed to many of our cells completely lacking MRP RNA (Fig. 3) in contrast to the cells retaining low levels of MRP, as is likely the case with RNAi experiments. In support of low levels of 
MRP RNA being sufficient for function, we observed that clones containing a tolerated mutation in $R M R P$ that leads to consistently diminished MRP RNA expression (Supplemental Fig. S2B) do not accumulate pre-rRNA in the manner that cells devoid of MRP RNA do (Supplemental Fig. S7B). This could implicate the robustness of the MRP RNP, where even severe depletion of RNP components provides a functional scenario, and the true null (or mutation) (see below) is required for defects to be observed.

\section{Disease alleles arise from the vulnerable MRP RNA locus}

While all four CRISPR guides targeting $R M R P$ efficiently cleaved the DNA, repair of these double-stranded breaks resulted in only small insertions or deletions at the predicted cut site (Fig. 1; Supplemental Fig. S2). However, for three out of four guides tested, these small indels were sufficient to disrupt MRP RNA accumulation and activity in the majority of cells, suggesting the sensitivity of MRP RNA to minute perturbation at distinct locations. The mechanism of this sensitivity remains underexplored and could be due to RNA destabilization (perhaps related to poor RNP assembly) or transcriptional effects. Patients with cartilage hair hypoplasia $(\mathrm{CHH})$ and related disorders also have small mutations in $R M R P$, and, as observed with our nonproliferating clones, these tiny differences appear to be sufficient to produce massive growth defects and compromised immune systems in these patients (Ridanpää et al. 2001). While direct assay of precise disease-causing mutations was beyond the scope of this work, our CRISPR experiments corroborate the susceptibility of the MRP RNA locus to deleterious mutation even when those mutations are minute, as with the disease alleles.

Each CRISPR guide analyzed here produced consistent proportions of cell populations missing MRP RNA (Fig. 2A), degree of rRNA precursor accumulation (Figs. 4, 5), and cleavage inhibition (Fig. 7D). However, there were distinct nuances in phenotype among the CRISPR guides. In particular, guide 4 had the highest proportion of nonproliferating cells (Fig. 2A) and a clear dramatic accumulation of the MRP RNA-dependent pre-rRNAs (Figs. 4C,D, 5D,E) yet, by Northern analysis, showed incomplete removal of MRP RNA (50\%-60\% of control) (see quantitation in Figs. 4A, 5B). Because Northern analysis reports on the relative expression/stability of MRP RNA and not the functionality of a stably expressed MRP RNA containing indels, it is possible that at least a fraction of the MRP RNA seen by Northern with guide 4 reflects somewhat stable expression of a nonfunctional (or even dominantnegative) mutated version of MRP RNA. The lack of rescue of pre-rRNA processing in guide 4-treated cells with ectopic wild-type MRP RNA further supports the nonfunctional nature of MRP RNAs expressed in guide 4treated cells (Fig. 5D,E). The functional capacity of expressed indel-containing MRP RNAs could also inform the disease mechanisms of $\mathrm{CHH}$, and the functional assays described here propel such future study.

\section{Toward a novel RNP cleavage mechanism}

The RNase MRP and RNase P RNPs have long been appreciated to have a common ancestor, presumably a ribozyme (Morrissey and Tollervey 1995; Zhu et al. 2006; Woodhams et al. 2007). Accordingly, spawned by the extreme ubiquity of RNase $\mathrm{P}$ and the robustness of tRNA folding in vitro, RNase MRP, particularly in humans, has largely been dismissed by the literature as an analogous enzyme perhaps unable to teach us anything new about enzymatic RNPs. Like P, whose penchant for the tRNA-like fold has incited numerous RNAs to hijack P's cleavage activity through structural mimicry (for example, Wilusz et al. 2012), MRP may have myriad substrates in various cellular contexts (Mattijssen et al. 2010; Mercer et al. 2011; Huang et al. 2015), and our data do not preclude the possibility that other yet unrecognized essential substrates exist in human cells. However, the study of pretRNA cleavage was how RNase P's substrate recognition and enzymatic mechanism were elucidated (Altman and Smith 1971; Guthrie 1975; Guerrier-Takada et al. 1983). Thus, future work with human pre-rRNA fragments is likely to inform the molecular details of RNase MRP cleavage activity.

Several factors suggest that MRP substrate recognition and cleavage may prove divergent from those of RNase P. First, others have reported three proteins $(\mathrm{Rpp} 21$, Rpp14, and hPOP4) that appear to associate only with RNase $\mathrm{P}$ in human cells (Welting et al. 2006), but, to our knowledge, no proteins have been reported to be unique to the human MRP RNP. Here we observed different protein compositions to be sufficient for MRP or P cleavage in vitro (Fig. 6C,D). Specifically, Rpp20 and Rpp30 are not detectable in our 3xF-Rpp38 elutions, and pre-tRNA is still easily cleaved, while ITS1 site 2 cleavage is severely debilitated. Furthermore, pre-tRNA cleavage is unperturbed by conjugation of the enzyme to bead resin (Supplemental Fig. S8C) or the presence of $\mathrm{Ca}^{2+} /$ EGTA in the reaction buffer (data not shown), while ITS1 site 2 cleavage is intolerant of these conditions. Finally, human RNase P cannot complement MRP RNA deficiency in vitro (Figs. 6, 7; Supplemental Fig. S5), in cells (Figs. 1-5), or in vivo (Ridanpää et al. 2001), as striking phenotypes were observed in our assays and in $\mathrm{CHH}$ patients that retain functional RNase P. These observations implicate a potentially unique mechanism for RNase MRP cleavage, and future work using mutagenesis of MRP RNA as well as its pre-rRNA substrates in vitro should help elucidate the enzymatic mechanism of this abundant essential RNP.

\section{Materials and methods}

All plasmids used in this study were deposited in Addgene.

\section{Cell culture and transfection of CRISPR machinery}

Plasmids for Cas9 and CRISPR guide RNA delivery were constructed from the plasmid px330 (Addgene, 42230) with the oligos in Supplemental Table S1 following the procedure of Ran et al. 
(2013) to produce plasmids px330-MRPsg1, px330-MRPsg2, px330-MRPsg3, and px330-MRPsg4. The plasmid referred to here as px330-sgNTC contained the original guide from the published plasmid (targeting GFP) (insert sequence reported in Supplemental Table S1). HeLa cells (TETsystems) were cultured in standard DMEM culture medium supplemented with $10 \%$ FBS and $1 \times$ penicillin/streptomycin (ThermoFisher) at $37^{\circ} \mathrm{C}$ with $5 \% \mathrm{CO}_{2}$. Eighteen hours to $24 \mathrm{~h}$ before transfection, 12-well plates were seeded with $1 \times 10^{5}$ cells per well in $1 \mathrm{~mL}$ of medium. After replacing the culture medium with fresh (antibiotic-containing) medium, each well was transfected with CRISPR-Cas9 plasmids ( $1 \mu \mathrm{g}$ of px330-sgNTC or px330-MRPsgX or $500 \mathrm{ng}$ each of two px330-MRPsgX) and $2 \mu \mathrm{L}$ of Lipofectamine 2000 (Invitrogen) in $100 \mu \mathrm{L}$ of OptiMEM (Gibco) according to the manufacturer's instructions. Twenty-four hours later ("day 1 after transfection"), wells were washed with PBS, trypsinized with $300 \mu \mathrm{L}$ of trypsin for $10 \mathrm{~min}$ at $37^{\circ} \mathrm{C}$, and quenched with $900 \mu \mathrm{L}$ of culture medium to produce "cell suspensions from day 1." Harvest for genomic DNA analysis, PCR, and sequencing are described in the Supplemental Material.

\section{Single-cell isolation}

Cell suspension from day 1 was diluted to $1 \times 10^{2}$ cells per milliliter in culture medium, and $150 \mu \mathrm{L}$ of the dilution was seeded per well of 96-well plates. Wells were manually screened for single colonies (eight to 16 cells close together) with the EVOS FL cell imaging system (Life Technologies) on day 5 after transfection, and annotated colonies were reimaged on day 14 for the proliferation phenotype. Phenotypes were categorized as "proliferating" if a colony greater than the field of view $(1.1 \mathrm{~mm} \times 0.83 \mathrm{~mm})$ was visible where an annotated colony had been on day 5 . "Slow/no proliferation" ranged from $\sim 50$ cells after 2 wk of daily doublings to the same eight cells from day 5 .

\section{RNA FISH}

Cell suspension from day 1 was diluted to $6 \times 10^{2}$ cells per milliliter in culture medium, and $150 \mu \mathrm{L}$ ( 90 cells) of the dilution was seeded per well of eight-well glass slides (LabTEK II, ThermoFisher). Wells were manually screened for single colonies by bright-field microscopy (EVOS FL, Life Technologies), as with single-cell isolation, on day 5 and harvested on day 10 after transfection when individual colonies of cells were still considerably separated within a well. For in situ harvest, culture medium was replaced with $200 \mu \mathrm{L}$ of culture medium containing 200 nM MitoTracker Red (Invitrogen), and live cells were incubated for $30 \mathrm{~min}$ at $37^{\circ} \mathrm{C}$. After four washes with $1 \times$ PBS, cells were fixed in $4 \%$ formaldehyde $/ 1 \times$ PBS for $30 \mathrm{~min}$ on ice, washed twice more with ice-cold $1 \times$ PBS, and permeablized with $0.8 \%$ Triton $/ 1 \times$ PBS (PBS-T) for $10 \mathrm{~min}$ on ice. Cells were rinsed once each with room temperature $1 \times$ PBS and $2 \times$ SSC before the wells were removed from the slides, and $50 \mu \mathrm{L}$ of freshly prepared Phil's buffer $(50 \%$ formamide, $10 \%$ dextran sulfate, $2 \times$ SSC, $125 \mu \mathrm{g} / \mathrm{mL}$ Escherichia coli tRNA, $1 \mathrm{mg} / \mathrm{mL}$ BSA, $500 \mu \mathrm{g} / \mathrm{mL}$ salmon sperm DNA [Invitrogen], $1 \mathrm{mM}$ vanadyl ribonucleoside complex [New England Biolabs]) was added to each well-less divided space. Slides were incubated in a humid chamber for $1 \mathrm{~h}$ at $37^{\circ} \mathrm{C}$, and prehybridization was removed and replaced with $30 \mu \mathrm{L}$ of Phil's buffer containing $55 \mathrm{nM}$ digoxigenin-labeled probes (5.8S_FISHprobe or ITS1_3'end_FISHprobe) and $180 \quad \mathrm{nM}$ Cy5-labeled MRP_3'end_FISHprobe. For FISH probes (Supplemental Table S1), DNA oligos (IDT) were labeled with the digoxigenin oligonucleotide tailing kit (Roche) according to the manufacturer's instructions or ordered with $5^{\prime} \mathrm{Cy} 5$ directly from IDT.
Hybridization took place overnight at $37^{\circ} \mathrm{C}$ in a humid chamber followed by three washes with $2 \times \mathrm{SSC}$ at $37^{\circ} \mathrm{C}$ and two washes with $1 \times$ SSC at room temperature. Slides were then refixed in $4 \%$ formaldehyde/ $1 \times$ PBS for $15 \mathrm{~min}$ at room temperature and washed twice with cold $1 \times$ PBS on ice. Two secondary antibodies were used to ensure strong FISH signal: First, sheep anti-DIGFITC (Jackson ImmunoResearch) at 1:200 dilution in PBS-T was applied to the slide for $1 \mathrm{~h}$ on ice in the dark. After washing twice with ice-cold PBS-T, donkey anti-sheep Alexa 488 (Molecular Probes, A11015) at 1:500 dilution in PBS-T was applied for $1 \mathrm{~h}$ on ice in the dark. The slide was given two more washes with cold PBS-T and two final washes with cold PBS before mounting with VectaShield (containing DAPI, Vector Laboratories). Slides were imaged on a Nikon A1R confocal microscope.

\section{Harvest for RNA analysis}

Cell suspension from day $1(100 \mu \mathrm{L})$ was transferred to a new well of a fresh 12-well plate containing $1 \mathrm{~mL}$ of medium. Cells were harvested with $1 \mathrm{~mL}$ of Trizol (Life Technologies) $72 \mathrm{~h}$ later ("day 4 after transfection") for RNA analysis (Northern, primer extension, and RNA-seq).

\section{Northern analysis (polyacrylamide gels)}

For visualization of RNAs $<500 \mathrm{nt}$ in length, $500 \mathrm{ng}$ of total RNA was separated on $6 \%$ polyacrylamide/7 M urea/1× TBE gels (MRP, P, snoU3, 5.8S, and 5S rRNA). RNA was transferred to Hybond $\mathrm{N}^{+}$membranes (GE Healthcare) in $1 \times \mathrm{TBE}$ at $1 \mathrm{amp}$ for $1 \mathrm{~h}$ at room temperature and then cross-linked at $1200 \mathrm{~mJ} / \mathrm{cm}^{2}$ before prehybridization in $10 \mathrm{~mL}$ of Church buffer $(0.5 \mathrm{M}$ sodium phosphate, $1 \mathrm{mM}$ EDTA, 7\% [w/v] SDS, 1\% [w/v] BSA) for 15 $\mathrm{min}$ at $50^{\circ} \mathrm{C}$. Northern probes were DNA oligonucleotides (IDT) $5^{\prime}$ end-labeled with polynucleotide kinase (New England Biolabs) according to the manufacturer's instructions with the following sequences: RNaseP_NP1 and RNaseP_NP2 (used simultaneously) (Xi and Cech 2014), MRP_NP, snoU3_NP, 5.8S_NP, and 5S_NP (Supplemental Table S1). For Northerns of immunoprecipitation fractions, $15 \mu \mathrm{L}$ of lysate or flowthrough or $10 \mu \mathrm{L}$ of elution was diluted with $180 \mu \mathrm{L}$ of $10 \%$ SDS and $20 \mu \mathrm{L}$ of $0.5 \mathrm{M}$ EDTA and heated for $5 \mathrm{~min}$ at $95^{\circ} \mathrm{C}$ before Trizol extraction as above. RNA pellets were resuspended in $15 \mu \mathrm{L}$ of water, and $7 \mu \mathrm{L}$ of the resuspension was loaded per lane.

\section{Northern analysis (agarose/formaldehyde gels)}

For high-molecular-weight RNAs, $0.5-3 \mu \mathrm{g}$ of total RNA was heated for $5 \mathrm{~min}$ at $70^{\circ} \mathrm{C}$ in $0.4 \mathrm{M}$ formaldehyde $/ 50 \%$ formamide/1× TT (30 mM tricine, $30 \mathrm{mM}$ triethanolamine)/0.5 mM EDTA, cooled to room temperature in a thermocycler, and separated on $1 \%$ agarose $/ 0.4 \mathrm{M}$ formaldehyde $/ 1 \times$ TT gels $(15 \mathrm{~cm} \times 15$ $\mathrm{cm} \times \sim 0.5 \mathrm{~cm})$ in $1 \times \mathrm{TT}$ at $130 \mathrm{~V}$ for $5 \mathrm{~min}$ followed by $100 \mathrm{~V}$ for $3.5 \mathrm{~h}$. The gels were rinsed with deionized water, soaked with gentle shaking for $15 \mathrm{~min}$ in $50 \mathrm{mM} \mathrm{NaOH}$, rinsed again with deionized water, and soaked with gentle shaking in $6 \times$ SSC for at least $15 \mathrm{~min}$. RNA was capillary-transferred to Hybond $\mathrm{N}^{+}$membranes (GE Healthcare) in 6× SSC overnight at room temperature with the following stack (bottom to top, "wet" indicates soaked in $6 \times$ SSC): glass plate, wick (wet), thick Whatman paper (wet), well-side-down gel (wet), membrane (wet), $2 \times$ thick Whatman paper (wet), $2 \times$ thick Whatman paper (dry), $\sim 2$-in-thick stack of paper towels (dry), and flat book $(<1 \mathrm{~kg})$. All items were cut to the same dimensions as the gel except for the glass plate, wick, and book, which had larger dimensions. Once transferred, membranes were treated as for polyacrylamide gels except that, for 
ITS1 probes, prehybridization was for $1 \mathrm{~h}$ at $65^{\circ} \mathrm{C}$, and hybridization was for $1 \mathrm{~h}$ at $65^{\circ} \mathrm{C}$ followed by overnight at $37^{\circ} \mathrm{C}$ and used the following probes: ITS1_3'end_NP, ITS1_mid_NP (Sloan et al. 2013), 18S_NP, 28S_NP, and 7SL_NP (Supplemental Table S1). Quantification of Northern analysis and heat maps for rRNA precursors are in the Supplemental Material.

\section{RNA-seq analysis}

RNA-seq library preparation and sequencing specifics are in the Supplemental Material. RNA-seq data were deposited in GenBank (SRP095139). PCR duplicates were removed from raw paired-end reads, and barcodes were trimmed off using the scripts associated with the Bioo Scientific kit. Deduplicated barcodetrimmed reads from all three lanes were then aligned to a minigenome consisting of a single copy of the human pre-rRNA gene NCBI reference NR_046235.1 using Bowtie with the following parameters "--best --chunkmbs 256 -m 1 -n 1 -q." To obtain overall coverage for each region of the pre-rRNA locus, the function "coverageBed" (BedTools) was used in conjunction with a Bed file stipulating the boundaries of the mature and precursors (i.e., $5^{\prime}$ ETS $=0: 3654,18 \mathrm{~S}=3655: 5523$, etc.). To determine the coverage at each base along the entire locus, "coverageBed" was used on the unsubdivided minigenome (i.e., pre-rRNA= $0: 13357$ ) invoking the "-d" option. The outputs of the latter (.sorted.bed files) were scaled to total coverage mapping to the rRNA locus for each sample and further analyzed using custom scripts (R project). For each MRP RNA-depleted sample, "relative coverage" was calculated as the scaled coverage at a specific nucleotide position along the pre-rRNA gene divided by the average of the scaled coverage for both controls at that nucleotide position. Positions with coverage greater than threefold above controls were considered significantly increased in a sample, as this was beyond the variation within control libraries. Nucleotide positions with zero coverage $(<10$ reads) in both controls but coverage ( $\geq 10$ reads) in the MRP RNA-depleted sample are indicated by solid bars below the axis with value -1 because these regions could not be divided by the zero average coverage in control samples. The average enrichment for all four MRP RNA-depleted samples was used to designate the consensus positions with significantly enriched coverage over average controls in all four MRP RNA-depleted samples.

\section{3xFlag-tagged MRP protein expression, immunoprecipitation,} and elution preparation

Construction of 3xFlag-tagged MRP protein plasmids is detailed in the Supplemental Material. Twelve-well plates were seeded with $1.2 \times 10^{5} \mathrm{HeLa}$ cells per well $16 \mathrm{~h}$ before each well was transfected with 300 ng of $3 \times$ Flag-RppX, 700 ng of carrier plasmid, and $2 \mu \mathrm{L}$ of Lipofectamine 2000 as per the manufacturer's instructions. Day 1 cell suspensions were prepared, and suspensions from eight identical wells were pooled onto a $15-\mathrm{cm}$ dish containing $30 \mathrm{~mL}$ of fresh medium. On day $4, \sim 80 \%$ confluent cells were washed with PBS, trypsinized $(3 \mathrm{~mL})$, and quenched with $10 \mathrm{~mL}$ of medium before transfer to a $15-\mathrm{mL}$ conical tube and pelleting by centrifugation at $1000 \mathrm{rpm}$. Cell pellets were washed with $4 \mathrm{~mL}$ of PBS and placed on ice. Five-hundred microliters of CHAPS lysis buffer $(10 \mathrm{mM}$ Tris at $\mathrm{pH} 7.5,1 \mathrm{mM} \mathrm{MgCl} 2,1 \mathrm{mM}$ EGTA, $0.5 \%$ CHAPS, $10 \%$ glycerol, $5 \mathrm{mM} \beta$-mercaptolethanol) was added to each pellet, and lysates were transferred to 1.7-mL Eppendorf tubes and nutated for $30 \mathrm{~min}$ at $4^{\circ} \mathrm{C}$. Insoluble chromatin $/ \mathrm{mem}$ branes were pelleted by centrifugation at $>13,000 \mathrm{~g}$ for $10 \mathrm{~min}$, and the supernatant was transferred to a fresh Eppendorf. For immunoprecipitation, $500 \mu \mathrm{L}$ of anti-Flag M2 affinity gel (Sigma) was washed four times with $1 \mathrm{~mL}$ of immunoprecipitation buffer 1 (20 mM Tris at pH 7.5, $150 \mathrm{mM} \mathrm{KCl}, 10 \mathrm{mM} \mathrm{MgCl}_{2}, 0.1 \%$ Triton $\mathrm{X}, 10 \%$ glycerol) and then resuspended in $250 \mu \mathrm{L}$ of immunoprecipitation buffer 1 to produce "anti-Flag-bead slurry." Anti-Flagbead slurry $(150 \mu \mathrm{L})$ was combined with $450 \mu \mathrm{L}$ of immunoprecipitation buffer 1 and $\sim 450 \mu \mathrm{L}$ of cleared lysate (this dilution is here termed "lysate" ) and rotated end over end for $2 \mathrm{~h}$ at $4^{\circ} \mathrm{C}$. Supernatant containing unbound cellular complexes was removed (designated "flowthrough"), and the remaining bound beads were eluted with $250 \mu \mathrm{L}$ of $230 \mathrm{ng} / \mu \mathrm{L}$ Flag peptide (Sigma) in immunoprecipitation buffer 1 by end-over-end rotation for $30 \mathrm{~min}$ at $4^{\circ} \mathrm{C}$. This elution was aliquoted and flash-frozen in liquid $\mathrm{N}_{2}$ for further analysis. Cotransfection of CRISPR machinery and 3xFlagRpp25 was performed similarly, except that $300 \mathrm{ng}$ of 3xFlagRpp25 was complemented with 1000 ng of px330-MRPsg1, px330-MRPsg2, and px330-MRPsg4 or px300-sgNTC with 2.6 $\mu \mathrm{L}$ of Lipofectamine 2000; four identically transfected wells were pooled onto a $15-\mathrm{cm}$ dish containing $30 \mathrm{~mL}$ of fresh medium. Cells were harvested as above and washed in $1 \mathrm{~mL}$ of PBS, cell pellets were lysed in $350 \mu \mathrm{L}$ of CHAPS lysis buffer, and 350 $\mu \mathrm{L}$ of lysis supernatant was mixed with $350 \mu \mathrm{L}$ of immunoprecipitation buffer 1 for immunoprecipitation with $60 \mu \mathrm{L}$ of anti-Flag bead slurry and Flag peptide eluted with $120 \mu \mathrm{L}$ of $150 \mathrm{ng} / \mu \mathrm{L}$ Flag peptide. Detailed methods for Western analysis of immunoprecipitation fractions are in the Supplemental Material.

\section{Transfection for ectopic MRP RNA expression}

Plasmid construction for ectopic MRP RNA/control RNA expression is detailed in the Supplemental Material. Twenty-four hours before harvest (on day 3 after cotransfection of CRISPR machinery and 3xFlag-Rpp25), 15-cm dishes were given $25 \mathrm{~mL}$ of fresh medium and transfected with $15 \mu \mathrm{g}$ of p-715MRPprom-tagonly [" (-) ectopic MRP RNA"] or p-715MRPprom-wtMRP [" (+) ectopic MRP RNA"] with $30 \mu \mathrm{L}$ of Lipofectamine 2000 in $1 \mathrm{~mL}$ of OptiMEM. Cell pellets were harvested by centrifugation as above and washed in $1 \mathrm{~mL}$ of PBS, and $100 \mu \mathrm{L}$ of the PBS wash resuspension was extracted with Trizol (prelysis) for RNA analysis. (rRNA precursors were pelleted during clarification of CHAPS lysis; thus, total RNA must be prepared from cells prelysis for pre-rRNA analysis.) The remaining washed cells were lysed as above for cotransfection.

\section{Preparation of body-labeled cleavage substrates}

Templates for cleavage substrates were cloned from genomic DNA using primers sub_XX_F1 and sub_XX_R1 (Supplemental Table S1). A typical 20- $\mu \mathrm{L}$ reaction contained $500 \mathrm{nM}$ each primer, 1× iQ SYBR Green Supermix (Bio-Rad), $500 \mu \mathrm{M}$ 7-deazaGTP (Roche), and $25 \mathrm{ng}$ of genomic DNA from HeLa cells with the following program: $10 \mathrm{~min}$ at $95^{\circ} \mathrm{C} ; 17$ cycles of $30 \mathrm{sec}$ at $95^{\circ} \mathrm{C}$, $30 \mathrm{sec}$ at $70^{\circ} \mathrm{C}-54^{\circ} \mathrm{C}\left(\mathrm{ramp}\right.$ rate $1^{\circ} \mathrm{C} / \mathrm{sec},-1^{\circ} \mathrm{C}$ per cycle), and 2 min at $72^{\circ} \mathrm{C}$; and 30 cycles of $30 \mathrm{sec}$ at $95^{\circ} \mathrm{C}, 30 \mathrm{sec}$ at $60^{\circ} \mathrm{C}$ (ramp rate $\left.1^{\circ} \mathrm{C} / \mathrm{sec}\right), 2 \mathrm{~min}$ at $72^{\circ} \mathrm{C}$, and $10 \mathrm{~min}$ at $72^{\circ} \mathrm{C}$. Amplicons were resolved on $1.5 \%$ agarose gels, and bands were excised for gel purification (Omega Bio-Tek). The template for precursor tRNA TYR from E. coli was obtained from pTYR-DNA (gift from Dr. Sidney Altman via Dr. Sumit Borah), which was linearized with FokI (New England Biolabs). Substrates were transcribed in microliter reactions with $\mathrm{T} 7$ polymerase; $40 \mathrm{mM}$ Tris (pH 8); $4 \mathrm{mM}$ spermidine; $20 \mathrm{mM} \mathrm{MgCl} 2 ; 10 \mathrm{mM} \mathrm{DTT} ; 5 \mathrm{mM}$ cold CTP, GTP, and ATP; $6 \mu \mathrm{M}$ cold UTP; $3 \mu \mathrm{M} \alpha_{-}{ }^{32}$ PUTP; and $\sim 20$ ng of gel-purified PCR or linear plasmid template. Transcription proceeded for $1 \mathrm{~h}$ at $37^{\circ} \mathrm{C}$ and was stopped with $35 \mu \mathrm{L}$ of $2 \times$ formamide loading dye $193 \%$ formamide, $30 \mathrm{mM}$ EDTA, $1 \times$ 
TBE, $0.05 \%$ bromophenol blue, $0.05 \%$ xylene cyanol). Reactions were heated for $10 \mathrm{~min}$ at $95^{\circ} \mathrm{C}$ and run on $6 \%$ polyacrylamide $/ 7$ $M$ urea/1 $\times$ TBE gels, and excised bands were eluted in TEN buffer (250 mM NaCl, 1 mM EDTA, 10 mM Tris at $\mathrm{pH}$ 8) for $30 \mathrm{~min}$ with rotation before ethanol precipitation.

\section{In vitro cleavage assays}

Body-labeled substrates were annealed in $50 \mathrm{mM}$ Tris ( $\mathrm{pH}$ 7.5) by heating for $3 \mathrm{~min}$ at $95^{\circ} \mathrm{C}$ and cooling to room temperature in a thermocycler. After at least $10 \mathrm{~min}$ at room temperature, $\mathrm{MgCl}_{2}$ was added for a final concentration of $10 \mathrm{mM}$. Each reaction contained $5 \mu \mathrm{L}$ of Flag peptide elution and $10^{4} \mathrm{cpm} / \sim 10$ $20 \mathrm{nM}$ ) of hot substrate in $1 \times$ activity buffer (final concentrations: $50 \mathrm{mM}$ Tris at $\mathrm{pH} 7.5,27.5 \mathrm{mM} \mathrm{KCl}, 10 \mathrm{mM} \mathrm{MgCl} 2,1 \mathrm{mM} \mathrm{DTT}$ ) and was incubated for $1 \mathrm{~h}$ at $37^{\circ} \mathrm{C}$. A more optimal activity buffer, M5 (differing only in final concentration of $5 \mathrm{mM} \mathrm{MgCl}_{2}$ ), was determined and used in 30-min reactions for all data in Figure 7. Reactions were stopped by phenol/chloroform extraction with ethanol precipitation and resolved on $6 \%$ polyacrylamide/7 $\mathrm{M}$ urea/ $1 \times$ TBE gels. Dried gels were imaged with a phosphorimager. Quantification of in vitro cleavage assays is detailed in the Supplemental Material.

\section{Competing interest statement}

T.R.C. discloses that he is on the board of directors of Merck, Inc.

\section{Acknowledgments}

We thank members of the Cech laboratory; Elaine Podell, Phil Richmond, Norm Pace, Roy Parker, and Sid Shukla at University of Colorado at Boulder; Howard Chang and Zhipeng Lu at Stanford University; Tim Welting at Maasticht University (Netherlands); and Ger Pruijn and Merel Derksen at Radboud University Nijmegen (Netherlands) for reagents, critical discussions, and scientific and technical advice. We also thank reviewer number 2 for helpful suggestions to optimize Northern analysis for prerRNAs. Additionally, we acknowledge the BioFrontiers and Biochemistry core facilities directors: Joe Dragavon (Advanced Light Microscopy), Jamie Prior Kershner (Next-Generation Sequencing), and Theresa Nahreini (Cell Culture). K.C.G. was supported by the National Institutes of Health Molecular Biophysics Training Scholarship (T32 GM-065103). T.R.C. is an investigator of the Howard Hughes Medical Institute. K.C.G. and T.R.C. conceived the study and wrote the manuscript. K.C.G. designed and carried out the experiments and analyzed the data. K.C.G. and T.R.C. read and approved the final manuscript for publication.

\section{References}

Altman S, Smith JD. 1971. Tyrosine tRNA precursor molecule polynucleotide sequence. Nat New Biol 233: 35-39.

Amar L, Desclaux M, Faucon-Biguet N, Mallet J, Vogel R. 2006. Control of small inhibitory RNA levels and RNA interference by doxycycline induced activation of a minimal RNA polymerase III promoter. Nucleic Acids Res 34: e37.

Barrangou R, Birmingham A, Wiemann S, Beijersbergen RL, Hornung V, Smith Av. 2015. Advances in CRISPR-Cas9 genome engineering: lessons learned from RNA interference. Nucleic Acids Res 43: 3407-3419.
Chang DD, Clayton DA. 1987. A novel endoribonuclease cleaves at a priming site of mouse mitochondrial DNA replication. EMBO J 6: 409-417.

Chu S, Archer RH, Zengel JM, Lindahl L. 1994. The RNA of RNase MRP is required for normal processing of ribosomal RNA. Proc Natl Acad Sci 91: 659-663.

Gill T, Aulds J, Schmitt ME. 2006. A specialized processing body that is temporally and asymmetrically regulated during the cell cycle in Saccharomyces cerevisiae. J Cell Biol 173: 35-45.

Guerrier-Takada C, Gardiner K, Marsh T, Pace N, Altman S. 1983. The RNA moiety of ribonuclease $P$ is the catalytic subunit of the enzyme. Cell 35: 849-857.

Guthrie C. 1975. The nucleotide sequence of the dimeric precursor to glutamine and leucine transfer RNAs coded by bacteriophage T4. J Mol Biol 95: 529-547.

Hadjiolova KV, Nicoloso M, Mazan S, Hadjiolov AA, Bachellerie JP. 1993. Alternative pre-rRNA processing pathways in human cells and their alteration by cycloheximide inhibition of protein synthesis. Eur J Biochem 212: 211-215.

Henras AK, Plisson-Chastang C, O'Donohue MF, Chakraborty A, Gleizes PE. 2015. An overview of pre-ribosomal RNA processing in eukaryotes. Wiley Interdiscip Rev RNA 6: 225-242.

Henry Y, Wood H, Morrissey JP, Petfalski E, Kearsey S, Tollervey D. 1994. The $5^{\prime}$ end of yeast 5.8S rRNA is generated by exonucleases from an upstream cleavage site. $E M B O J$ 13: 2452-2463.

Huang W, Thomas B, Flynn RA, Gavzy SJ, Wu L, Kim SV, Hall JA, Miraldi ER, Ng CP, Rigo FW, et al. 2015. DDX5 and its associated lncRNA Rmrp modulate $\mathrm{T}(\mathrm{H}) 17$ cell effector functions. Nature 528: 517-522.

Jaag HM, Lu Q, Schmitt ME, Nagy PD. 2011. Role of RNase MRP in viral RNA degradation and RNA recombination. J Virol 85: 243-253.

Lindahl L, Bommankanti A, Li X, Hayden L, Jones A, Khan M, Oni T, Zengel JM. 2009. RNase MRP is required for entry of $35 \mathrm{~S}$ precursor rRNA into the canonical processing pathway. RNA 15: 1407-1416.

Lopez MD, Rosenblad MA, Samuelsson T. 2009. Conserved and variable domains of RNase MRP RNA. RNA Biol 6: 208-220.

Lygerou Z, Allmang C, Tollervey D, Seraphin B. 1996. Accurate processing of a eukaryotic precursor ribosomal RNA by ribonuclease MRP in vitro. Science 272: 268-270.

Mattijssen S, Welting TJ, Pruijn GJ. 2010. RNase MRP and disease. Wiley Interdiscip Rev RNA 1: 102-116.

Mattijssen S, Hinson ER, Onnekink C, Hermanns P, Zabel B, Cresswell P, Pruijn GJ. 2011. Viperin mRNA is a novel target for the human RNase MRP/RNase P endoribonuclease. Cell Mol Life Sci 68: 2469-2480.

Mercer TR, Neph S, Dinger ME, Crawford J, Smith MA, Shearwood AM, Haugen E, Bracken CP, Rackham O, Stamatoyannopoulos JA, et al. 2011. The human mitochondrial transcriptome. Cell 146: 645-658.

Morrissey JP, Tollervey D. 1995. Birth of the snoRNPs: the evolution of RNase MRP and the eukaryotic pre-rRNA-processing system. Trends Biochem Sci 20: 78-82.

Mullineux ST, Lafontaine DL. 2012. Mapping the cleavage sites on mammalian pre-rRNAs: where do we stand? Biochimie 94: 1521-1532.

Piccinelli P, Rosenblad MA, Samuelsson T. 2005. Identification and analysis of ribonuclease $\mathrm{P}$ and MRP RNA in a broad range of eukaryotes. Nucleic Acids Res 33: 4485-4495.

Ran FA, Hsu PD, Wright J, Agarwala V, Scott DA, Zhang F. 2013. Genome engineering using the CRISPR-Cas9 system. Nat Protoc 8: 2281-2308. 
Ridanpää M, van Eenennaam H, Pelin K, Chadwick R, Johnson C, Yuan B, vanVenrooij W, Pruijn G, Salmela R, Rockas S, et al. 2001. Mutations in the RNA component of RNase MRP cause a pleiotropic human disease, cartilage-hair hypoplasia. Cell 104: 195-203.

Rogler LE, Kosmyna B, Moskowitz D, Bebawee R, Rahimzadeh J, Kutchko K, Laederach A, Notarangelo LD, Giliani S, Bouhassira E, et al. 2014. Small RNAs derived from lncRNA RNase MRP have gene-silencing activity relevant to human cartilage-hair hypoplasia. Hum Mol Genet 23: 368-382.

Rosenblad MA, Lopez MD, Piccinelli P, Samuelsson T. 2006. Inventory and analysis of the protein subunits of the ribonucleases $\mathrm{P}$ and MRP provides further evidence of homology between the yeast and human enzymes. Nucleic Acids Res 34: 5145-5156.

Rosenbluh J, Nijhawan D, Chen Z, Wong KK, Masutomi K, Hahn WC. 2011. RMRP is a non-coding RNA essential for early murine development. PLoS One 6: e26270.

Shadel GS, Buckenmeyer GA, Clayton DA, Schmitt ME. 2000. Mutational analysis of the RNA component of Saccharomyces cerevisiae RNase MRP reveals distinct nuclear phenotypes. Gene 245: 175-184.
Sloan KE, Mattijssen S, Lebaron S, Tollervey D, Pruijn GJ, Watkins NJ. 2013. Both endonucleolytic and exonucleolytic cleavage mediate ITS1 removal during human ribosomal RNA processing. J Cell Biol 200: 577-588.

Welting TJ, Kikkert BJ, van Venrooij WJ, Pruijn GJ. 2006. Differential association of protein subunits with the human RNase MRP and RNase P complexes. RNA 12: 1373-1382.

Welting TJ, Peters FM, Hensen SM, van Doorn NL, Kikkert BJ, Raats JM, van Venrooij WJ, Pruijn GJ. 2007. Heterodimerization regulates RNase MRP/RNase P association, localization, and expression of Rpp20 and Rpp25. RNA 13: 65-75.

Wilusz JE, JnBaptiste CK, Lu LY, Kuhn CD, Joshua-Tor L, Sharp PA. 2012. A triple helix stabilizes the $3^{\prime}$ ends of long noncoding RNAs that lack poly(A) tails. Genes Dev 26: 2392-2407.

Woodhams MD, Stadler PF, Penny D, Collins LJ. 2007. RNase MRP and the RNA processing cascade in the eukaryotic ancestor. BMC Evol Biol 7: S13.

Xi L, Cech TR. 2014. Inventory of telomerase components in human cells reveals multiple subpopulations of hTR and hTERT. Nucleic Acids Res 42: 8565-8577.

Zhu Y, Stribinskis V, Ramos KS, Li Y. 2006. Sequence analysis of RNase MRP RNA reveals its origination from eukaryotic RNase P RNA. RNA 12: 699-706. 


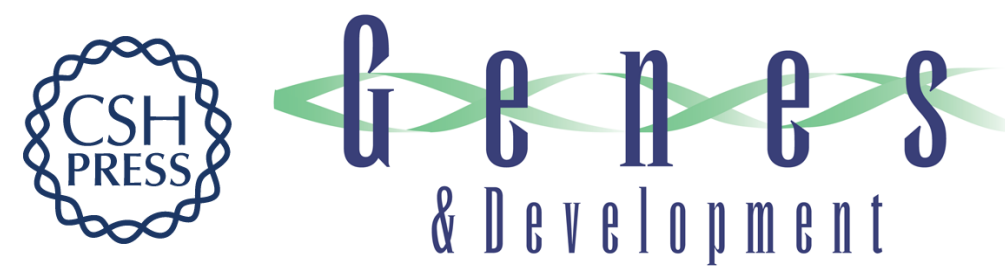

\title{
Targeted CRISPR disruption reveals a role for RNase MRP RNA in human preribosomal RNA processing
}

\author{
Katherine C. Goldfarb and Thomas R. Cech
}

Genes Dev. 2017, 31: originally published online January 23, 2017

Access the most recent version at doi:10.1101/gad.286963.116

\section{Supplemental http://genesdev.cshlp.org/content/suppl/2017/01/23/gad.286963.116.DC1 Material}

References This article cites 35 articles, 10 of which can be accessed free at: http://genesdev.cshlp.org/content/31/1/59.full.html\#ref-list-1

Creative This article is distributed exclusively by Cold Spring Harbor Laboratory Press for the first Commons six months after the full-issue publication date (see

License http://genesdev.cshlp.org/site/misc/terms.xhtml). After six months, it is available under a Creative Commons License (Attribution-NonCommercial 4.0 International), as described at http://creativecommons.org/licenses/by-nc/4.0/.

Email Alerting Receive free email alerts when new articles cite this article - sign up in the box at the top Service right corner of the article or click here.

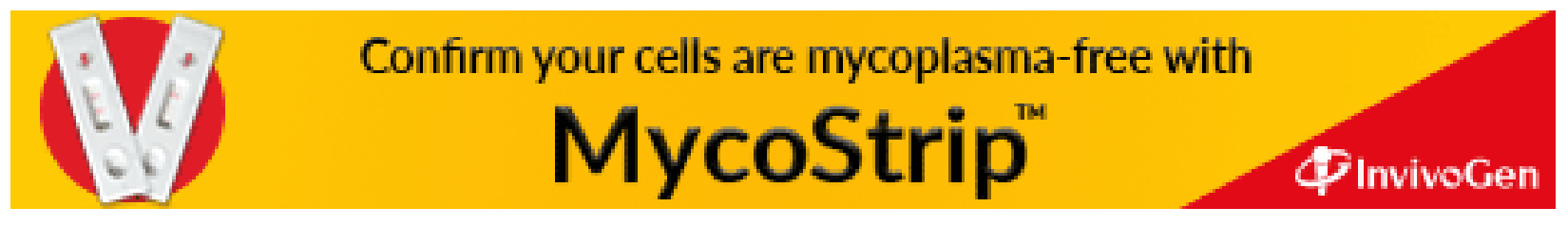

